\title{
IOS 5
}

Volume 2 (1) (2019): 44-50

\section{The Indonesian Journal of Social Studies}

\author{
Available at https://journal.unesa.ac.id/index.php/jpips/index
}

\section{Improve Creative Thinking Ability With Posing Problem Learning}

\author{
Supriyanto ${ }^{1)^{*}}$, Nasution ${ }^{2)}$, Wisnu ${ }^{3)}$ \\ 1) Postgraduate Social Sciences Education, Universitas Negeri Surabaya, Indonesia \\ 2) Fakultas Ilmu Sosial dan Hukum, Universitas Negeri Surabaya, Indonesia \\ 3) Fakultas Ilmu Sosial dan Hukum, Universitas Negeri Surabaya, Indonesia
}

\begin{abstract}
Abstrak
Tujuan artikel ini adalah untuk menggambarkan keterampilan berpikir kreatif siswa dalam pembelajaran sosial menggunakan model Problem Posing. Subjek dalam penelitian ini adalah 28 siswa kelas delapan SMP Negeri 1 Tulangan tahun akademik 2019. Peneliti menggunakan data primer dan teknik pengumpulan data, yaitu tes. Tes dilakukan sebelum dan sesudah belajar. Hasil penelitian menunjukkan bahwa hasil tes independent sample t-test posttest kemampuan berpikir kreatif peserta didik menunjukkan bahwa terdapat perbedaan kemampuan berpikir kreatif antara kelas eksperimen dan kelas kontrol setelah diberi perlakuan. Berdasarkan analisis uji-t, disimpulkan bahwa model pembelajaran problem posing mempengaruhi kemampuan berpikir kreatif siswa. Penelitian ini bermanfaat bagi guru, yaitu mereka dapat mengembangkan wawasan guru untuk menjadi lebih inovatif dan kreatif dalam menciptakan kegiatan belajar yang menyenangkan di kelas dan meningkatkan kompetensi pengetahuan siswa dan kemampuan berpikir kreatif. Model pembelajaran problem posing diimplementasikan ke dalam kelas karena dapat meningkatkan kemampuan berpikir kreatif dan memahami dalam mengatasi masalah dan konflik yang terjadi di masyarakat dan diharapkan dapat mengoptimalkan kemampuan berpikir kreatif.

Kata Kunci: problem posing model, berpikir kreatif, STAD, pembelajaran IPS
\end{abstract}

\section{Abstract}

The purpose of this study is to describe the students' creative thinking skills in social studies learning using the Problem Posing model. The subjects in this study were 28 eighth grade students of SMP Negeri 1 Tulangan academic year 2019. Researchers used primary data and data collection techniques, namely tests. Tests were carried out before and after learning. The results showed that the test results of independent sample t-test posttest creative thinking abilities of learners shows that there are differences in the ability of creative thinking between the experimental class and class control after being given treatment. Based on the analysis of the t-test, it was concluded that the problem posing learning model influenced students' creative thinking abilities. This research is useful for teachers, that is, they can develop teacher insights to be more innovative and creative in creating fun learning activities in the classroom and increasing students' knowledge competencies and creative thinking abilities. The problem posing learning model is implemented into the class because it can improve the ability of creative thinking and understanding in addressing problems and conflicts that occur in society and is expected to optimize the ability to think creatively.

Keywords: problem posing model, creative thinking, social studies learning

How to Cite: Supriyanto, Nasution, \& Wisnu. (2019). Improve Creative Thinking Ability With Posing Problem Learning. The Indonesian Journal of Social Studies, Vol 2(1): 44-50

*Corresponding author:

E-mail: suvri_2009@yahoo.co.id
e-ISSN 2615-5966 (Online)

This is an open access article under the CC-BY-SA license 


\section{INTRODUCTION}

Students understanding of the social sciences is necessary in order to solve the problems of the economy in the form of limited resources owned and growing needs. Article 37 of the National Education System Law of 2003 places social studies education as a compulsory subject for every level of primary and secondary education which aims to foster sensitivity in the community and develop knowledge. Social studies is formulated in a systematic, comprehensive and integrated manner that is expected to help students to gain extensive and deep knowledge. The National Council for Social Studies (1994) also explains that 21st century learning and thinking skills need to be developed by IPS for students: (1) Critical thinking skills and Problem Solving , (2) Contextual learning skills, (3) Communication, (4) Information literacy and media, (5) Creativity and innovation skills, and (6) collaboration skills (collaboration).

The development of ideas and ideas is based on students' social experiences in community life. Social experience is the basis of thinking ability (Sanjaya, 2010). Social studies learning at the junior high school level is expected to help students solve problems and make decisions through thinking and analysis.

Thinking is a mental ability of a person who is grouped into 5 namely creative thinking, logical, analytical, critical, systematic and critical. Logical thinking is to draw conclusions based on previous knowledge that students have correctly. Analytical thinking is the ability to understand knowledge logically by deciphering and detailing it. Systematic thinking is completing tasks effectively and efficiently in the right order or planning. Critical thinking rational thinking about things diya $\mathrm{k}$ is true, while creative thinking is the ability to think with unique solutions, unusual and new way (Santrock: 2014).

Previous research on creative thinking in the world of education was written in international journals, among others: mechanisms to improve creative thinking skills based on Extenics (Chena at al. 2015), creative training in visual and multimedia arts (Ulger, 2016; Kassim, 2013). From the field of reading and writing research has been conducted to explore the relationship of creative thinking to reading and writing (Wang, 2012). In the music field music education programs focus on creative thinking (Corakli \& Batibay, 2012). Other studies related to gender are effects of gender and thinking styles on students' creative thinking abilities (Piaw, 2014) .

The reality found in the field is how low the students' creative thinking skills are.P social studies learning at SMP Negeri 1 Tulangan does not develop students' creative thinking abilities. This lack of thinking ability of students is seen where students tend to be passive when receiving lessons. Learning tends to only transfer knowledge on the other hand students also show an attitude that is less enthusiastic and lazy. The low level of creative thinking is also caused during the learning process is still often at levels C1 (knowledge) and C2 (understanding). In addition, the daily test score does not reach KKM. This can be seen when the discussion activities in the class of 6 active group members are only 2-3 people, meaning that $40 \%$ of students are active and participating. Then when the group discussion presentation results only $30 \%$ of students were able to communicate well.

In order for students to think creatively increasing , learning innovations are needed, namely using the Problem Posing model with material "Economic actors and their role in the economy" can foster students' knowledge in exploring the economic actors in their respective regions so students can exchange ideas with other students . By using the Problem Posing learning model expected to increase students' understanding of the material. $\mathrm{P}$ roblem $\mathrm{p}$ osing learning model to create a varied environment by getting to know students (Wahab, 2007) . 
In the Problem Posing learning process, learning begins with the submission of problems or questions from students based on existing information. In the implementation of this learning helps students to formulate problems based on topics or material that has been explained by the teacher so that it is more in depth accompanied by solutions and solutions (Thobroni, 2015). Problem posing can be done individually or in groups, because both contribute to students ' understanding. In groups, can establish mutually beneficial cooperation and develop the ability to solve problems rationally because students can discuss with group friends. Individually the submission of questions can help students be more independent and active in learning, questions that are asked individually have the opportunity to be solved first carefully and seriously so that this will optimize the student's learning outcomes. The p roblem p osing learning model has several advantages including increasing the activity of students so that they are more active in learning, have fighting power, confidence and have thoughts to solve problems.

Based on the background of the problem, the formulation of the problem in this research is b How can the influence of the learning model p roblem $p$ Osing on students' creative thinking abilities in the material of economic actors and their role in the economy? The aim of this enelitian P u ntuk analyze a model of learning how to influence the $\mathrm{p}$ roblem $\mathrm{p}$ Osing the ability to think creatively .

\section{METHOD}

The approach used in this study is quantitative, where research that processes data in the form of numbers in the form of quantitative. (Sugiyono, 2013). Quasi Experimental Design is a type of research used by researchers. Nonequivalent control group design is the design used in this study (Sugiyono, 2015: 116). The design was similar to the pretest-posttest control group design , but in Nonequivalent control group design the experimental group and the control group were not randomly selected. The sample selection uses a saturated sample technique where all members of the population are used as samples. In this study the variables are independent variable 1 (X 1 ): p roblem p osing model . Dependent variable 1 (Y 1 ): Ability to think creatively . Class VII I-B and VIII-D are the subjects in this study which took place at SMP Negeri 1 Tulangan Sidoarjo in semester 2 of the 2018/2019 academic year.

Sugiyono (2018) said that the basis for decision-making on whether or not the research hypothesis is based on the ratio of tcount to ttable at the $5 \%$ significance level with information if $t$ count is greater than $\mathrm{t}$ table ( $\mathrm{t}$ count $>\mathrm{t}$ table ), then null hypothesis (Ho ) rejected and alternative hypothesis (Ha) is accepted later if tcount is smaller than ttable (tcount $<$ ttable ) null hypothesis (Ho) is accepted and the alternative hypothesis ( $\mathrm{Ha}$ ) is rejected.

Next is the basis of testing the hypothesis by paying attention to Sig (2-tailed) , if Sig (2-tailed) $<0.05$, it means that there is influence from the treatment given but if Sig (2-tailed) $>0.05$, then there is no influence from giving treatment (Priyatno: 2014 ). The hypothesis is said to be nil (Ho) if the problem posing learning model does not affect the ability to think creatively then the hypothesis is said to be alternative (Ha) if the problem posing learning model influences the ability to think creatively. The sample from this study is a class sample. The sampling technique is done bysimple random sampling, which is the determination of the sample by drawing draws without regard to the strata that exist in the population. The data collection technique for motivation variable (Y1) uses aquestionnaire Likert scale with a score of 1-4. The knowledge variable (Y2) uses a written test. All data obtained will be tested for assumptions and variance homogeneity tests. If the prerequisites are fulfilled, the data analysis usesparametric statistics independent smple t-test. 


\section{RESULT AND DISCUSSION}

Validate learning devices by experts in the field of education before the research is conducted. The validator in this study was (1) Dr. Agus Suprijono, M.Pd Unesa post-graduate lecturer, and (2) Dr. Sukma Prime Prasetya, S.Pd., MT, a lecturer S1 P Education IPS Un iversitas Negeri Surabaya. Experimental class and class control are two classes used in this study. Class e ks perimen given treatment by using model $\mathrm{p}$ roblem $\mathrm{p}$ Osing and grade control model can pembel a direct distance (d irect i nstruction). Before being practiced to the learning device class consisting of learning syllabus, lesson plans, learning outcomes test instruments, LKPD (creative thinking instruments) students and handouts are validated first by experts. Research instruments that have been validated by experts are then practiced in the trial class first to determine the level of implementation in learning. Then for the instrument the assessment of the results is analyzed for the level of validity and reliability.

\section{Test the validity of the item}

The questions that will be tested must be tested first validity by validity test so that they are accurate and accurate in carrying out the measuring function. $R$ umus product moment correlation from Karl Pearson used to calculate item validity . $\mathrm{R}$ xy calculation results are then compared to the numbers in the table of product moment, with level s ignifikansi 5\%. Item questions are said to be valid if the result of the calculation is $r x y \geq r$ table. Criteria $r$ xy like the table below. Based on the trials of 16 items there are 10 valid questions and the remaining 6 items are invalid. The 10 valid questions are then used as data collection instruments in real research in experiment and control classes.

Table 1. Summary of Validity Test Results

\begin{tabular}{|c|c|c|}
\hline No. & Correlation Value & Information \\
\hline 1 & 0.683 & Valid \\
\hline 2 & 0.516 & Valid \\
\hline 3 & 0.724 & Valid \\
\hline 4 & 0.848 & Valid \\
\hline 5 & 0.555 & Valid \\
\hline 6 & 0.664 & Valid \\
\hline 7 & 0.729 & Valid \\
\hline 8 & 0.755 & Valid \\
\hline 9 & 0.672 & Valid \\
\hline 10 & 0.598 & Valid \\
\hline
\end{tabular}

Item number 10 valid, then tested the reliability level. Reliability shows the degree of stability or reliability of an instrument in carrying out its function as a measuring instrument. The level of reliability of a test is expressed in a number of reliability coefficients. To calculate the reliability of essay questions. Cronbach Alpha formula for testing description questions (Arikunto, 2008).

the results of the Alpha test instrument reliability test analysis are 0,884 . This shows that the results of the overall analysis of instrument items are reliable, so this research instrument is suitable to be used to retrieve data.

The study was conducted in junior high school Negeri 1 Reinforcement where VIII-B as the control class that uses a conventional learning while VIII-D as a class experiment that uses a learning 
model problem posing. The initial activities carried out by the researcher gave the pretest questions in the experimental class and the control class alternately. This is to find out the results of students' creative thinking abilities in the material of economic actors and their role in the economy before learning using the problem posing model .

The average value of learning outcomes using the problem posing learning model on the ability of creative thinking of students to solve social studies questions about economic actors before being given (pretest) the average value in the control class 64 and the average in the experimental class 62. Mean in the table 4:13 (statistical tables pretest) experimental group was 61.96 with a standard deviation is 9.709 and in table 4:14 (po statistics table stest $t$ ) the experimental group was 85.00 with a standard deviation is 7.822 . While the mean in table 4.13 (statistical table pretest ) of the control group is 63.79 with standard deviation 9.079 and in table 4.14 (postestt statistical table ) the experimental group is 76.68 with the standard deviation 8.807 .

The average value of learning outcomes uses the problem posing learning model for students' creative thinking abilities to solve social studies questions about economic actors and their role in the economy after being given problem posing learning models . On average in the class $\mathrm{k}$ ontrol the experimental class 77 and 85. It can be concluded that creative thinking abilities of students in the experimental group was higher than $\mathrm{k}$ ontrol group. The problem posing learning model has a positive effect on students' creative thinking abilities.

\section{Hypothesis Testing Results Creative Thinking Ability}

Hypothesis testing begins with the pretest in the control class and the experimental class, then posttest in the experimental and control classes. Test the independent sample t-test at pretest with the aim of measuring the similarity of the experimental and control classes before treatment. After that, the posttest aimed to see the difference in influence that was caused in both classes after being given treatment.

Hypothesis formulation of students' creative thinking abilities as follows.

Ha: There is the influence of using the problem posing model on the creative thinking.

Ho: There is no effect on the use of the problem posing model on the creative thinking abilities of class VIII students.

Vvalues $t$ which is 0.650 . The value of $t$ table at (df.54) significance of 0.05 is 1.674 (Priyatno: 2016). if compared then $t$ count $<t$ table with the results of Sig. 2 tailed equals $0.518>0.05$ and it can be said that $\mathrm{H} \mathrm{o}$ is accepted which means there is no significant difference in the students' creative thinking ability when the pretest is performed. The results of the independent sample ttest after the treatment are as follows. $\mathrm{N}$ use values $\mathrm{t}$ which is 3,738 . The value of $\mathrm{t}$ table at (df.54) significance of 0.05 is 1.674 (Priyatno: 2016). When compared then $t$ count $>t$ table with the results of Sig. 2 tailed is $0,000>0,05$ and it can be said that $\mathrm{H}$ a is accepted which means that there is a significant difference in the students' creative thinking ability when done posttest .

Independent sample test results t-test the pretest of students' creative thinking skills showed no difference in creative thinking skills between the experimental class and the control class before being given treatment. While the results of the independent sample test t-test $\mathrm{p}$ ostest creative thinking abilities of learners shows that there are differences in the ability of creative thinking between classroom control and experimental group after being given treatment. Based on the 
analysis above, it can be concluded that the problem posing learning model influences students' creative thinking abilities.

Learning in this study refers to theme 3 with the material of economic actors and their role in the economy. To facilitate students in learning according to the material to be discussed, this activity begins by dividing the class into several study groups. Hiterogen group formation. The formation of groups in learning activities is intended to train students' creative thinking skills, so that students can solve the problems given in the form of a group's ability to think creatively. Which calls it ZPD, zona proximal development where a child can do something without the help of adults and whether a child can do something with adult direction or cooperation with peers. Students with their group friends discuss to solve the problems given in the form of tests of creative thinking skills. With discussions conducted by students, it is expected that students can be open with divergent thinking, so that when completing individual TBK, students have been trained beforehand to solve a problem they face. The researcher gave the opportunity to each group to present the results of their group's work in front of their friends.

The task of solving problems with the creative thinking ability provided can strengthen students in their learning abilities to be more creative in their thinking. This is in line with the theory expressed by Vygotsky (in Suyono, 2011: 110) that cognitive development is generated from a dialectical process in which a student learns through problem solving experience will be used to share with others.

The problem posing learning model can help students realize the knowledge they have acquired and can be applied to new situations, and this process guides students to acquire new knowledge. Using the problem posing learning model allows students to be more creative in solving problems they face in their daily lives.

The implementation of each step in good learning is supported by the ability of researchers to manage learning that is reflected in behavior when implementing teaching (Sanjaya, 2010). The implementation of good learning is certainly very close to the quality of learning that has been prepared, besides that, the readiness of researchers in applying learning techniques in learning becomes very important. By designing a posing learning model it aims to establish optimal ways to structure, organize the content of the material in the learning process in order to achieve meaningful knowledge.

\section{CONCLUSION}

Based on data analysis, it was concluded that there was a positive influence on the problem posing learning model on students' creative thinking abilities. There is a significant difference in the creative thinking abilities of students who use the problem posing learning model and conventional learning models. The problem posing learning model has a positive influence on the ability to think creatively, so that the results of the test of creative thinking ability can increase than before. The average value in the dick group is 77 , and the average value in the experimental group is 85 . Thus this study managed to reject Ho at the $5 \%$ significance level. Furthermore, it can be concluded that Ha is proven correct. It can be concluded that the problem posing learning model has a positive effect on creative thinking skills in social studies learning class VIII in SMP Negeri 1 Tulangan Sidoarjo. The advice that the author can give related to the problem under study is the problem posing learning model implemented into the class because it can improve students' creative thinking skills. 


\section{REFERENCES}

Anderson, L. W. and Krathwoh, D. R. (2014). Learning, Teaching and Assessment . Yogyakarta. Student Library

Arikunto, S. (2010). Research Procedure: An Approach to Practice . Jakarta: Rineka Cipta

Barret, T and Cashman, D. (2010). Practitioners Guide and Inquiry and Problem Based Learning . UCD Teaching and Learning

Hanafiah, N. \& Suhana, C. (2010). The Concept of Learning Strategies . Bandung: Refika Aditama

Indarti, T (2008). Classroom Action Research (CAR) and Scientific Writing. Surabaya; Unesa FBS Publisher Institute

Johnson, D.W, Johnson, R.T, \& Holubec, E.J. (2012). Colaborative Learning Learning Strategies for Success Together . Bandung: Nusa Media

Klurik, S. \& Rudnick, J. A. (1995). The New Sourcebook for Teaching Reasoning and Problem Solving in Elementary School . Needham Height, Massachusetts: Allyn \& Bacon

Nur, M. (2011) Learning Model Based on Problems. Surabaya: Unesa School of Science and Mathematics Center

Priyatno, D. (2014). SPSS 22 Terpractical Data Processing. Yogyakarta: Andi Offset

Priyatno, D. (2016). SPSS Handbook Data Analysis, Data Analysis and Resolving Statistic Cases . Yogyakarta: MediaKom

Purwanto. (2014). Evaluation of Learning Outcomes . Yogyakarta: Student Library

Santrock, J. W. (2014). Educational Psychology Educational Psychology . Jakarta: Salemba Humanika

Sanjaya, V. (2010). Learning Strategy . Jakarta, Kencana Prenada Media Group

Schunk, DH (2012). Learning Theories . Yogyakarta: Student Library

Silver, Edward A and Cai, Jinfa (1996). " An Analysis of Arithmetic Posing Problem by Middle School Students ". Journal for Research in Mathematics Education, Volume 27. No 5, p. 521 539

Sugiyono, (2011). Quantitative, Qualitative Research and $R \& D$ Methods . Bandung: Alfabeta

Suprijono, A. (2009), Cooperative Learning: Theory and Application of Paikem . Yogyakarta: Student Library

Sundayana, R. (2014). Educational Research Statistics . Bandung: Alfabeta 